\title{
Endelig et norsk hjerteinfarktregister
}

I etterkrigstiden så man en dramatisk økning av iskemisk hjertesykdom. Fra 1947 til 1960 ble frekvensen femdoblet, noe som skapte stor bekymring. Regjeringen satte ned en komité som i 1963 leverte en innstilling om sammenhengen mellom fettforbruket i kosten og hjerte- og karsykdommer (1). Komiteen foreslo kostendringer som skulle kunne forebygge sykdommen, men også at myndighetene skulle overvåke befolkningens sykelighet og dødelighet av hjerte- og karsykdommer. Tanken om å registrere hjerteog karsykdommer ble lagt frem allerede ved etableringen av Det norske råd for hjerte- og karsykdommer i 1955, og i 1961 inngikk rådet en avtale med Kreftregisteret om et samarbeid (2). Senere ble det uenighet både om lokalisering og registerets karakter. Først i 2010 vedtok Stortinget at det skulle opprettes et personidentifiserbart, landsdekkende register. Fra 1.1.2012 er alle sykehus pålagt å melde inn helsedata om pasienter innlagt med diagnosen akutt hjerteinfarkt i Norsk hjerteinfarktregister. I dette nummeret av Tidsskriftet kan vi lese den første artikkelen fra dette registeret (3).

En sykdoms letalitet er en funksjon av sykdommens farlighetsgrad og hvor effektiv behandlingen er. Forandringer i insidens reflekterer endringer i årsaksfaktorer i befolkningen. I 1960-årene var dødeligheten av hjerteinfarkt et godt substitutt for insidens, og den betydelige geografiske variasjonen som man så mellom Finnmark, som sammen med Oslo tronet på toppen av dødelighetsstatistikken, og Sogn og Fjordane, som hadde lagt seg på et bunnivå, var trolig uttrykk for en reell forskjell i sykdomsrisiko (4). Behandlingen var i prinsippet virkningsløs, og det var mer flaks og tilfeldigheter som gjorde at pasientene overlevde og unngikk å komme inn i statistikken.

Samtidig var man klar over at dødsårsaksstatistikk har svake sider. Et klinisk basert register koblet til et dødsårsaksregister er nødvendig for å kunne beskrive insidens, dødelighet og virkning av behandling.

Hovedformålet til det norske hjerteinfarktregisteret er å samle og presentere data som kan brukes til å bedre kvaliteten på behandlingen av pasienter med hjerteinfarkt i Norge. Et viktig delmål er å gi bedre og sammenliknbare opplysninger om antall og behandling av hjerteinfarkt ved norske sykehus og slik medvirke til gode tjenestetilbud og pasientforløp. Behandlingen av pasienter med akutt koronarsykdom er utviklet til en avansert klinisk teknologisk virksomhet. Det er utarbeidet algoritmer og retningslinjer som skal sikre best mulig resultat for hver enkelt pasient. Hjerteinfarktregisteret vil gjøre det mulig å vurdere i hvilken grad slike retningslinjer følges opp, og dermed sikre lik behandling over hele landet. Dette forutsetter at data som legges inn i registeret, er valide, og både dataprodusenten og den sentrale mottakeren har et stort ansvar. Jortveit og medarbeidere tar for seg registreringsåret 2013, det første året med tilnærmet fullstendige data (3). Enkelte sykehus fulgte ikke opp sine forpliktelser, og rapporteringen er noe ujevn. Det reduserer verdien av registeret og gjør det vanskelig for det enkelte sykehus å vurdere egne behandlingsresultater. Metodene for dataregistrering varierer foreløpig mellom sykehusene, noe som bør følges opp i tiden fremover. Datasettene for hver enkelt pasient er ellers på det nærmeste komplett når det gjelder risikofaktorer, behandling og tidligere sykdom. Samtidig er det et tankekors at røyking, som er den variabelen som betyr mest for senere forløp (hos røykerne), er dårligst registrert.

Et av artikkelens viktigste funn er at 30-dagers letalitet er omtrent den samme over hele landet. Om lag én av ti innlagte pasienter med akutt hjerteinfarkt er død etter 30 dager. Det burde vise at norske sykehus hevder seg godt også i internasjonal sammenheng. Men samtidig påpeker forfatterne at man har usikre opplysninger om tid fra symptomdebut til innleggelse. Om man ikke tar hensyn til dette, kan nærmest identisk letalitet skjule forskjeller i behandlingsresultat mellom ulike sykehus. Man angir vanligvis at to tredeler av de som dør innen 30 dager etter et akutt hjerteinfarkt, dør utenfor sykehuset. Om denne andelen varierer mellom ulike regioner på grunn av avstand og transportmuligheter, vil dødsrisiko variere mellom dem som kommer til sykehusbehandling. Av den grunn bør man forsøke å få bedre informasjon om tid fra symptomdebut til behandling. En annen sak er at en forbedring av overlevelsesmuligheten i sykehus betyr at dødsfall utenfor sykehus får en relativt større betydning (5).

I og med at hjerteinfarktregisteret er et sykehusbasert register gir det ikke en fullstendig oversikt over hjerteinfarktsykdommens frekvens i Norge. Endringer i insidensen av hjerteinfarkt, og ikke minst letaliteten av sykdommen, vil vi få fra Hjerte- og karregisteret der Norsk hjerteinfarktregister inngår som et av flere kvalitetsregistre sammen med Dødsårsaksregisteret. I Sverige har man vist at 28-dagers letalitet for alle pasienter med infarkt samlet, både de som er innlagt på sykehus, og de som dør utenfor sykehus, varierer mellom 20 og vel $40 \%$, avhengig av alder ved første infarkt (5). Det er med andre ord langt flere enn én av ti som dør ved sitt første infarkt.

I tillegg til å overvåke kvalitet kan registeret også brukes for spesifikke forskningsformål, som endepunktregister i kliniske utprøvinger, eller for å se etter mulige interaksjoner og bivirkninger ved kobling til andre registre. I en fersk oversiktsartikkel over koronarsykdommens epidemiologi i USA setter man slike registre i et større perspektiv (6). Utviklingen over tid for årsakspesifikk dødelighet og letalitet må ses i sammenheng med ny kunnskap om ateroskleroseutvikling, risikofaktorer og behandlingstiltak. Langsgående studier av forløp og utvikling er nødvendige instrumenter for å sikre optimal behandling av pasientene. Om noen år kan vi for alvor begynne å høste av det norske hjerteinfarktregisteret.

\section{Dag Steinar Thelle \\ d.s.thelle@medisin.uio.no}

Dag Steinar Thelle (f. 1942) er spesialist i indremedisin og professor emeritus ved Universitetet i Oslo og Göteborgs universitet. Han er medansvarlig for oppstart av hjerte- og karundersøkelsene i Troms $\varnothing$ og helseundersøkelsen i Oslo (HUBRO).

Forfatter har fylt ut ICMJE-skjemaet og oppgir ingen interessekonflikter.

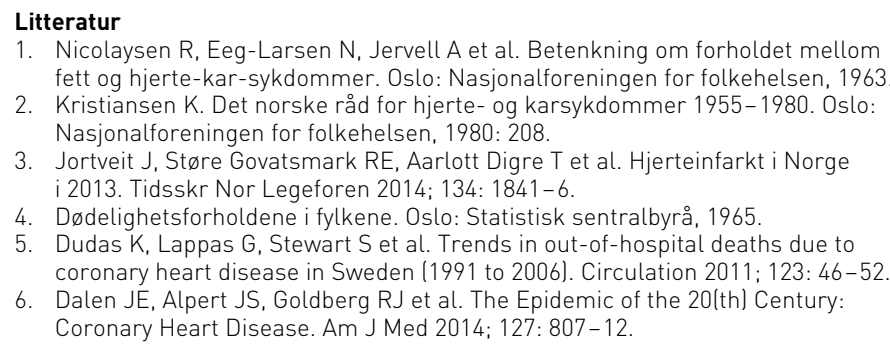

